\title{
PELESTARIAN BAHASA MELAYU SEBAGAI BAHASA IBUNDA DI SINGAPURA
}

\author{
(PRESERVING THE MALAY LANGUAGE AS \\ A MOTHER TONGUE IN SINGAPORE)
}

\author{
Aishah Mohamad Kassim \\ clsamk@ nus.edu.sg \\ Faculty of Arts and Social Sciences \\ National University of Singapore \\ Singapore
}

Received: 5th September 2021; Accepted: 4th October 2021; Published: 26th October 2021

\begin{abstract}
The latest statistics from the Department of Statistics in Singapore (2020) shows that more Malay families speak English at home. However, this trend is common across all ethnic groups in Singapore. Over the five decades of independence and enforcement of the bilingualism policy, the Malay language, which is the National Language and language commonly spoken in Malay households, is gradually being replaced with English. Other statistics reveal that the Malay language, which is the mother tongue of the majority of the Malays, is used less frequently, even from the early years of socialisation in a Malay household and the exposure of Malay only begins at the preschool level (Maliki, 2020). There is an assumption that, as long as the government maintains the Malay language in the education system through language learning in Singaporean schools, the bilingual policy will continue to maintain the usage of vernacular language. This development is likely to create more issues towards learning and teaching the Malay language as a mother tongue. Hence, this study utilises the approach of the sociology of language to discuss the reasons and impact of the language shift in efforts to preserve the status of the Malay language among the Singapore Malays.
\end{abstract}

Keywords: teaching and learning of Malay language, sociology of language, language status, language maintenance, language shift, mother tongue.

\begin{abstract}
Abstrak
Dengan data terkini yang menunjukkan lebih banyak keluarga Melayu berbahasa Inggeris di rumah terdapat trend di mana bahasa Melayu sebagai bahasa pertuturan di rumah-rumah orang Melayu juga semakin berkurangan (Department of Statistics, Singapore, p. 2020). Ada anggapan selagi pemerintah mengekalkan penggunaan bahasa Melayu dalam sistem pendidikan melalui pembelajaran bahasa di sekolah-sekolah Singapura, dasar dwibahasa ini sedikit sebanyak akan dapat mengekalkan terus penggunaannya di sekolah-sekolah. Dari data kajian terkini juga terdapat taksiran yang menunjukkan bahasa Melayu semakin tidak digunakan sejak awal dari rumah lagi, maka pendedahan bahasa Melayu hanya bermula di sekolah sahaja (Maliki, p. 2020). Perkembangan ini dijangka menimbulkan lebih banyak
\end{abstract}


masalah pembelajaran dan pengajaran bahasa Melayu sebagai bahasa ibunda. Kertas ini meninjau secara terperinci perubahan ini dan mengambil pendekatan sosiologi bahasa bagi perbincangan tentang sebab dan kesan peralihan bahasa Melayu dalam usaha pelestarian bahasa dalam masyarakat Melayu Singapura.

Kata Kunci: pengajaran dan pembelajaran bahasa Melayu, sosiologi bahasa, status bahasa, peralihan bahasa, pemeliharaan bahasa, bahasa ibunda.

\section{Pengenalan}

Perbincangan tentang pengajaran dan pembelajaran bahasa Melayu sebagai bahasa ibunda secara am tertumpu kepada usaha-usaha guru dalam sistem pendidikan Singapura untuk menarik dan mengekalkan minat para pelajar terhadap bahasa Melayu. Pada hakikatnya, ruang penggunaan bahasa Melayu di luar rumah orang Melayu khususnya di Singapura, semakin mengecil. Perubahan dalam kedudukan bahasa Melayu berlaku akibat perubahan sosio-politik dan budaya yang pesat di Singapura. Kesannya adalah terhadap bahasa Melayu yang pada awal pembentukan negara ialah bahasa kebangsaan dan bahasa ibunda orang Melayu. Pada hakikatnya sekarang, bahasa Melayu walaupun masih dianggap bahasa kebangsaan, dengan jelas sudahpun menjadi hanya salah satu subjek yang diajar di sekolahsekolah di Singapura (MOE, 2020).

Data terkini menunjukkan lebih banyak keluarga Melayu berbahasa Inggeris di rumah (Department of Statistics, 2020), dan terdapat trend memperlihatkan bahasa Inggeris secara perlahan akan menjadi sebagai bahasa pertuturan di rumah. Menurut perangkaan ini, penggunaan bahasa Melayu semakin berkurangan. Walau bagaimanapun masih ada anggapan dalam kalangan masyarakat Melayu bahawa selagi pemerintah mengekalkan penggunaan bahasa Melayu dalam sistem pendidikan melalui pembelajaran bahasa di sekolah-sekolah Singapura, dasar dwibahasa ini sedikit sebanyak akan terus dapat mengekalkan penggunaan bahasa Melayu dalam kalangan orang Melayu.

Cabaran paling ketara adalah perubahan struktural masyarakat Melayu Singapura yang terutamanya hidup dalam lingkaran masyarakat bandar yang majoriti bukan Melayu dan hubungan kekeluargaan yang semakin mengecil. Kesannya ialah bahasa Melayu yang sepatutnya memainkan peranan utama sebagai wadah sosiolisasi di rumah dilihat semakin rapuh. Hal ini akan dibincangkan seterusnya dalam kajian ini dengan melihat pada statistik yang dikeluarkan oleh Kementerian Pendidikan (MOE). Sudah terdapat tanda-tanda awal yang menunjukkan bahasa Melayu tidak digunakan sejak awal lagi di rumah. Pendedahan bahasa hanya berlaku di sekolah dan hal ini menimbulkan tanda tanya sama ada proses peralihan ini akan terus berlaku dan menimbulkan lebih banyak masalah pembelajaran dan pengajaran bahasa Melayu sebagai bahasa ibunda.

Pada tahun 2019, 67 peratus keluarga Melayu yang mempunyai anak dalam Darjah 1 menggunakan bahasa Inggeris sebagai bahasa komunikasi utama di rumah (Maliki, 2020). Profil pelajar Melayu dalam Darjah 1 ini menimbulkan cabaran dalam pemerolehan dan pembelajaran bahasa ibunda di sekolah. Dasar dwibahasa sepanjang lima dekad selepas Singapura mencapai kemerdekaan merupakan faktor luaran yang menyumbang kepada peralihan bahasa ini. Pelbagai masalah pembelajaran bahasa akan dihadapi jika kanak-kanak Melayu tidak menggunakan bahasa ibunda dari awal pendidikan mereka di rumah. 
Kajian ini bertujuan meninjau corak perubahan yang berlaku dalam penggunaan bahasa dan mengambil pendekatan sosiologi bahasa bagi membincangkan tentang kesan perubahan status bahasa Melayu terhadap masyarakat Melayu Singapura dan sebaliknya. Khususnya, beberapa faktor yang mendorong atau menghalang peralihan bahasa (language shift) dan pengaruh pertembungan bahasa terutama bahasa rasmi, iaitu bahasa Inggeris dalam masyarakat Melayu Singapura. Data-data yang digunakan ialah data yang dikeluarkan oleh Jabatan Statistik Singapura tentang kajian mengenai corak penggunaan bahasa dalam kalangan warga Singapura terutama masyarakat Melayu Singapura. Pendekatan yang diambil dalam kajian ini ialah Pendekatan Sosologi bahasa yang turut menenerangkan proses dan mekanisme peralihan bahasa dalam konteks tempat, masa dan masyarakat. Teori peralihan dan pemeliharaan bahasa telah dipelopori oleh Joshua Fishman (1989).

\section{Konsep Peralihan Bahasa (LS)}

Kajian mengenai peralihan dan pemeliharaan bahasa (language maintenance) berkaitan dengan hubungan pengguna bahasa dengan bahasa-bahasa lain yang terdapat dalam sesebuah masyarakat. Hubungan ini berlaku apabila dua atau lebih bahasa diperlukan dalam satu-satu situasi. Hubungan bahasa dalam konteks masyarakat majmuk contohnya dan pemilihan bahasa terutama bagi sesebuah negara yang pernah dijajah dan mendapat kemerdekaan akan mengakibatkan peralihan bahasa kepada bahasa utama yang dipilih dan dianggap lebih penting dalam soal pendidikan dan kerjaya.

Bagi membuat analisis tentang peralihan bahasa, maka timbul pula konsep pemeliharaan bahasa (LM) dalam menghadapi perubahan dan menentukan kestabilan dalam penggunaan bahasa terutamanya bahasa ibunda. Menurut Fishman (1989), beberapa faktor yang berkaitan menimbulkan kesulitan dalam membincangkan hal peralihan bahasa. Para pengkaji harus meneliti varian bahasa yang penutur gunakan dan dengan siapa serta di mana bahasa itu terus digunakan. Dalam perbincangan berkenaan pemeliharaan bahasa, Fishman (1989) mengutamakan analisa 'penggunaan bahasa biasa' dalam masyarakat bagi pengekalan satu-satu bahasa itu. Penekanan terhadap sikap pengguna bahasa terhadap bahasa mereka dan dasar atau perancangan bahasa turut mempengaruhi fenomena peralihan atau pemeliharaan bahasa.

Analisis data tentang statistik penduduk oleh jabatan statistik akan digunakan bagi memahami trend dalam masyarakat majmuk di Singapura. Dengan menggunakan statistik ini, penyelidikan bahasa dapat memerhatikan trend penggunaan bahasa Inggeris dan Melayu. Melalui perbincangan peralihan bahasa terdapat juga beberapa usaha masyarakat dan persepsi mereka tentang usaha pemeliharaan dalam menangani peralihan bahasa supaya kadar peralihan dapat dikawal. Usaha melestarikan bahasa juga secara amnya selaras dengan cadangan Fishman bagi memastikan penggunaan bahasa terus dikekalkan. Usaha-usaha masyarakat Melayu Singapura juga akan dibincang bagi menggambarkan bagaimana masyarakat memandang masalah penggunaan dan pengekalan bahasa ibunda ini berkaitan dengan usaha melestarikan bahasa dan budaya mereka

\section{Implikasi Daripada Dasar Dwibahasa dan Kesan Terhadap Bahasa Ibunda}

Kedwibahasaan merupakan tunjang sistem pendidikan Singapura. Kepentingan kedwibahasaan ini diulang-ulang dan masih termaktub dalam dasar kurikulum kebangsaan 
Singapura dari peringkat pra-sekolah hingga ke peringkat pos-menengah dan maktab rendah. Setiap kanak-kanak di Singapura wajib mempelajari Bahasa Ibunda (MTL) ${ }^{1}$ mereka sebagai bahasa kedua di sekolah-sekolah kebangsaan oleh kerana keyakinan yang pembelajaran bahasa-bahasa ini akan "memberi manfaat kepada pelajar Singapura" dan juga bagi memupuk "jati diri pelajar-pelajar di sini".

Dalam dasar nasional, bahasa Inggeris dianggap mempunyai kepentingan yang setara dengan bahasa Melayu. Pada umumnya sejak awal tahun 1965 lagi selepas Singapura mencapai kemerdekaan, bahasa Inggeris telah dianggap sebagai bahasa perpaduan dan penyatuan rakyat. Maka ia kekal kukuh sebagai bahasa pengantar dan bahasa utama dalam sistem pendidikan malah dalam segala aspek pentadbiran negara, undang-undang, pendidikan, perniagaan dan perindustrian.

Bahasa Melayu, bahasa Mandarin dan bahasa Tamil sebaliknya diwajibkan sebagai 'bahasa ibunda' kepada setiap pelajar dalam sistem pendidikan nasional di sini. Bahasa Melayu diajar kepada pelajar berbangsa Melayu sebagai bahasa ibunda dan bukan lagi sebagai bahasa kebangsaan. Para pelajar etnik Cina dan India juga akan mempelajari MTL mereka masing-masing. Pelajar yang berbangsa 'Eurasian' (atau disebut Serani) dan yang mempunyai keturunan campuran atau yang bahasa ibunda mereka bukan salah satu MTL rasmi, boleh memohon untuk mempelajari mana-mana bahasa tertakluk kepada kebenaran yang diberikan oleh kementerian. Ada juga pelajar bukan berbahasa etnik India memohon untuk belajar bahasa Melayu atau bahasa India yang bukan Tamil (Bengali, Gujarati, Hindi, Punjabi atau Urdu). Kelas-kelas bahasa ini tidak disediakan oleh Kementerian Pendidikan (MOE) dan biasanya dijalankan di luar premis dan waktu sekolah.

Latar belakang ini penting bagi memahami punca 'peralihan bahasa' (language shift) dalam kalangan pelajar-pelajar Melayu, iaitu yang mengalami peralihan kepada bahasa Inggeris. Peralihan ini walaupun boleh dikaitkan secara makro kepada perancangan bahasa tetapi perubahan-perubahan lain yang berlaku dalam konteks sosiobudaya kehidupan masyarakat Singapura terutama orang Melayu sebagai kaum minoriti yang tinggal di Singapura juga akan dipaparkan bagi memahami keadaan peralihan bahasa Melayu kepada bahasa Inggeris yang berlaku secara perlahan dalam masyarakat Melayu itu sendiri.

Dalam hal ini, sistem terkini pengajaran bahasa Melayu di sekolah-sekolah Singapura boleh dibahagikan kepada dua kelompok pelajar, iaitu yang berbangsa Melayu (MTL) dan kepada yang bukan Melayu (Malay Special Programme (MSP)). Para pelajar yang belajar Bahasa Melayu di sekolah-sekolah kebangsaan adalah mereka yang secara umumnya digolongkan dalam kategori berbangsa Melayu. Mereka wajib mengambil Bahasa Melayu sebagai bahasa ibunda di sekolah.

Walaupun Bahasa Melayu dianggap bahasa kebangsaan pada kedudukannya, kategori pelajar yang bukan Melayu pula hanya digalakkan (tidak diwajibkan) mempelajari Bahasa Melayu, iaitu bukan sebagai bahasa ibunda tetapi Bahasa Melayu sebagai bahasa ketiga. Program Bahasa Ketiga (MSP) selalunya diajar kepada kohort pelajar-pelajar yang mendapat markah cemerlang dalam keputusan peperiksaan akhir sekolah rendah (PSLE). Para pelajar sekolah menengah yang mengambil Bahasa Melayu dalam program khas berpeluang mengambil peperiksaan umum sijil am peringkat biasa (GCE-O). Ada beberapa bahasa asing

\footnotetext{
${ }^{1}$ Bahasa Ibunda (Mother Tongue Language_MTL) ditawarkan di sekolah-sekolah Singapura sebagai bahasa kedua dan merupakan mata pelajaran wajib.
} 
yang lain turut ditawarkan. Oleh yang demikian, tidak ramai mengambil atau mempelajari bahasa Melayu kerana bukan subjek yang diwajibkan. Hanya beberapa buah sekolah sahaja yang menawarkan bahasa Melayu komunikasi, iaitu untuk sekadar memahami dan mengenali budaya orang Melayu di Singapura.

Bahasa Melayu turut diajar dalam program-program pengenalan di sekolah-sekolah tertentu. Program-program ini selalunya tidak ada sebarang penilaian khas. Perkara ini dianggap sebagai subjek tambahan kurikulum tanpa peperiksaan. Pada masa ini, beberapa sekolah arus kebangsaan menyediakan program bahasa Melayu sebagai 'bahasa komunikatif' kepada murid-murid pra-sekolah, sekolah rendah hingga pelajar peringkat sekolah menengah. Oleh sebab kurang pendedahan kepada bahasa Melayu, bahasa Melayu yang tidak digunakan dalam konteks kehidupan mereka dilupai atau tidak digunakan langsung.

Pada peringkat universiti atau institusi pengajian tinggi, program Bahasa Melayu turut ditawarkan sebagai bahasa ketiga atau digolongkan dalam fakulti bahasa-bahasa asing. Walau bagaimanapun, pelajaran berbentuk modular ini dianggap elektif yang tidak wajib malah diambil sebagai modul tambahan. Program serupa ini terdapat di beberapa buah universiti tempatan seperti Universiti Nasional Singapura (NUS), di Universiti Teknologi Nanyang (NTU) dan Universiti Pengurusan Singapura (SMU).

\section{Penggunaan Bahasa Inggeris Terus Meningkat}

Penggunaan bahasa Inggeris yang terus meningkat di rumah-rumah orang Melayu telah dikaji sejak awal 1990. Peralihan bahasa dalam masyarakat telah dikesan sedekad selepas dasar dwibahasa diperkenalkan. Malahan trend bahasa Inggeris menjadi bahasa pertuturan atau bahasa 'basahan' di rumah dalam kalangan penduduk Melayu jati Singapura telah dikesan sejak sedekad pengenalan sistem nasional. Sejak tahun 1990 lagi dalam kajian kertas penyelidikan (Abdullah, Kamsiah \& Bibi Jan Ayyub, 1998; Roksana, 1990) terdapat kesan daripada peralihan bahasa terutama dalam kalangan mereka yang berpendidikan tinggi dan peningkatan dalam penggunaan bahasa Inggeris sebagai bahasa pengantar dalam masyarakat Melayu.

Dalam kajian di atas ini, terdapat penggunaan bahasa Melayu yang lebih banyak antara cucu dengan datuk atau nenek mereka; daripada dengan ibu dan bapa Melayu mereka. Dalam penyelidikan Kamsiah Abdullah (2000) menunjukkan bahawa dengan lenyapnya sekolah-sekolah Melayu, iaitu sekolah Melayu yang terakhir telah ditutup pada tahun 1987, menyebabkan status BM sebagai bahasa ibunda dalam sistem pendidikan turut menjejaskan penggunaan bahasa Melayu.

Dalam huraian Jabatan Statistik Singapura (2020) secara purata bilangan penduduk Singapura sudah meningkat kepada 5.69 juta rakyat dan penduduk yang dikategorikan sebagai bangsa Melayu membentuk hanya 13.4 peratus daripada jumlah penduduk keseluruhan negara Singapura ini atau lebih kurang 545 ratus ribu orang penduduk. Lebih kurang 34 peratus adalah mereka yang masih bersekolah. Pencapaian dalam bidang pendidikan secara amnya terus meningkat. Ini bermakna lebih ramai yang lulus daripada institusi-institusi pos-menengah di Singapura, yang menggunakan bahasa Inggeris sebagai bahasa pengantar dalam sistem pendidikan. 
Peningkatan penggunaan bahasa Inggeris dalam masyarakat setempat di Singapura juga memaparkan pengurangan domain-domain sosial yang menggunakan bahasa Melayu sebagai bahasa perantaraan masyarakat Cina dan India dengan masyarakat Melayu di Singapura. Status bahasa Melayu sebagai bahasa kebangsaan juga semakin kurang ditekankan. Bahasa Melayu juga diberikan status bahasa rasmi yang sama dengan bahasabahasa rasmi yang lain termasuk Inggeris, Mandarin dan Tamil. Sehingga kini jelas kelihatan dalam beberapa poster yang dikeluarkan oleh mana-mana jabatan di kementerian. Contohnya dapat dilihat seperti dalam rajah di bawah:

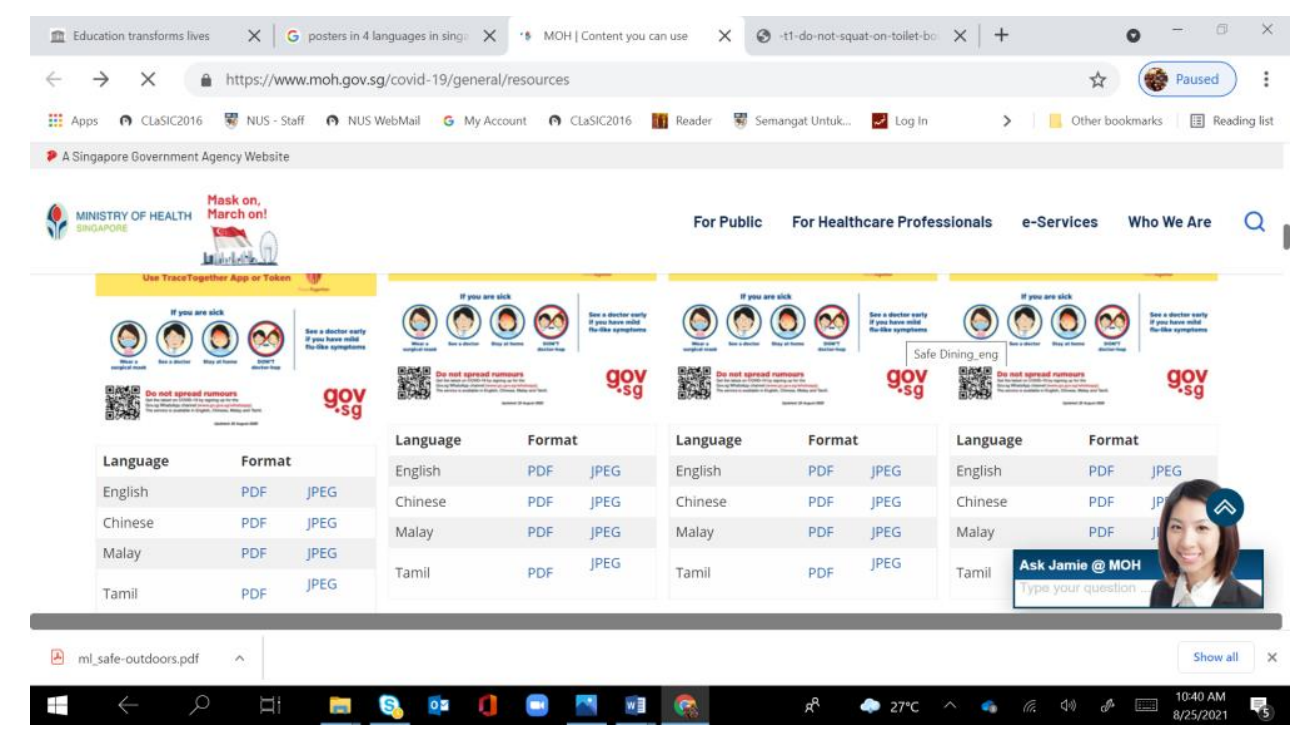

Rajah 1: Poster dalam Empat Bahasa Rasmi

Dengan pengenalan akta Pendidikan Wajib yang diluluskan pada tahun 2000, semua kanak-kanak berkerakyatan Singapura diwajibkan (MOE, 2021) mendaftar ke sekolahsekolah pemerintah dan sekali gus harus mematuhi dasar dwibahasa yang menetapkan penggunaan bahasa Inggeris sebagai bahasa rasmi dan bahasa ibunda (bahasa Mandarin, bahasa Melayu dan bahasa Tamil) kepada orang Cina, Melayu dan India.

Dengan penekanan ini, bermulalah satu era baru dalam pendidikan orang-orang Melayu Singapura. Walau bagaimanapun, unsur bahasa masih dikekalkan sebagai ciri pembeza jati diri utama antara orang Melayu, India dan Cina di Singapura dan juga sebagai identiti dwibahasa bagi masyarakat Singapura di rantau ini. Selepas lebih daripada lima dekad mencapai kemerdekaan, status BM sebagai bahasa kebangsaan turut berubah dan persoalan seperti adakah kumpulan pelajar generasi $\mathrm{X}$, generasi $\mathrm{Y}$ dan generasi seterusnya akan dapat melestarikan pengguasaan bahasa BM, semakin diperkatakan. Jelas sekali dalam perangkaan yang didedahkan baru-baru ini penggunaan bahasa Melayu dalam kalangan remaja dan orang dewasa terutama karyawan muda Singapura semakin berkurangan. Gambaran yang jelas ini terlihat dalam tinjauan yang telah dikeluarkan oleh Jabatan Statistik Singapura ${ }^{2}$ baru-baru ini memperlihatkan lebih ramai dalam kalangan masyarakat Singapura yang menggunakan bahasa Inggeris di rumah.

\footnotetext{
${ }^{2}$ Data daripada Department of Statistics and Infografik daripada from CAN.
} 


\section{LANGUAGE MOST FREQUENTLY SPOKEN AT HOME FOR RESIDENT POPULATION AGED 5 AND ABOVE}
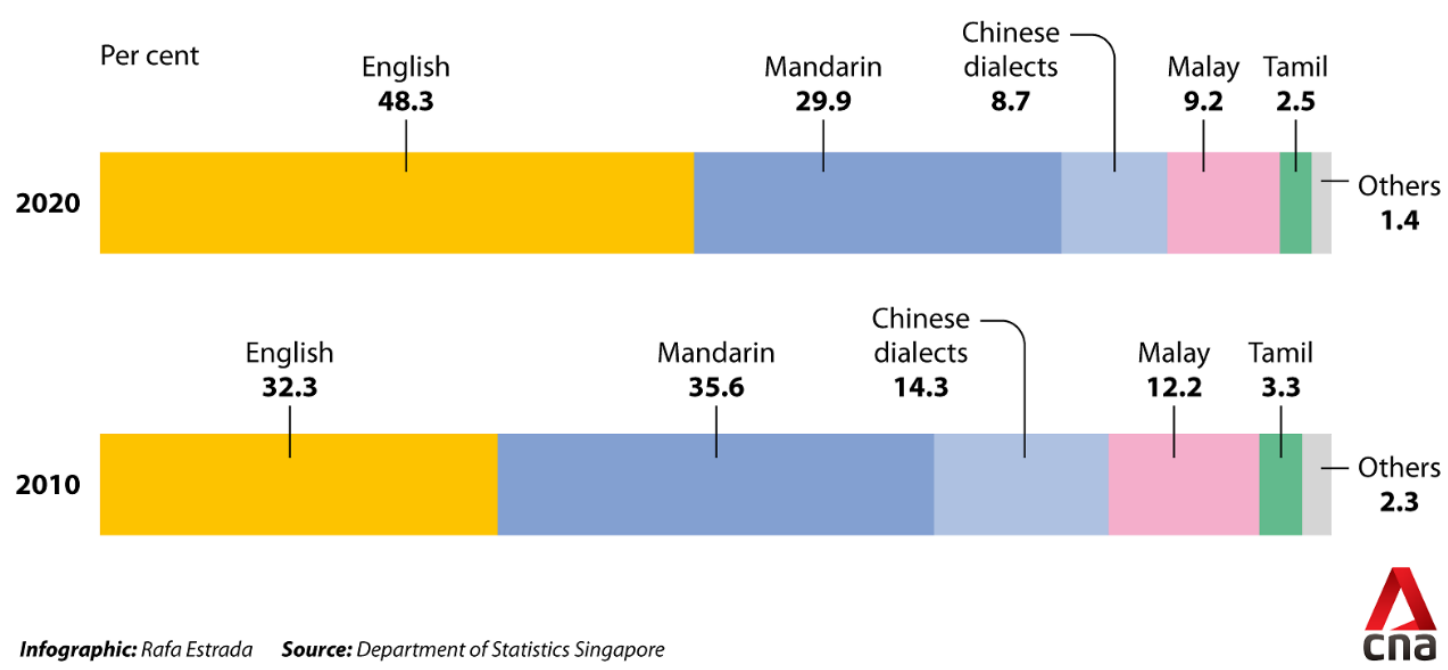

Rajah 2: Bahasa yang Sering Digunakan di Rumah Bagi Penduduk Daripada Umur 5 Tahun dan ke Atas.

Secara umumnya $48.3 \%$ rakyat Singapura menggunakan bahasa Inggeris sebagai bahasa pertuturan di rumah. Dalam tinjauan ini, perangkaan ini juga menunjukkan dalam kalangan orang Melayu yang menggunakan bahasa Melayu di rumah juga merosot daripada $12.2 \%$ hingga ke $9 \%$. Terdapat tambahan peratusan dalam penggunaan bahasa Inggeris di rumah-rumah orang Melayu juga.

Walaupun data statistik ini menunjukkan kemerosotan dalam penggunaan bahasa Melayu di rumah-rumah penghuni berbangsa Melayu, data seperti ini masih tidak mencukupi untuk memberikan gambaran yang jelas tentang interaksi yang berlaku dalam satu-satu domain sama ada pengguna bahasa masih berperanan dalam mengekalkan penggunaan bahasa Melayu (Pauwels, A., 2016).

Menurut Pauwels (2016), walaupun statistik menunjukkan peralihan bahasa (LS), perangkaan ini merupakan perubahan perilaku penutur bahasa, perbezaan lebih terperinci antara penggunaan bahasa dalam generasi pertama dan kedua, contohnya akan dapat juga digunakan sebagai penelitian kepada LS dalam satu-satu keadaan sosial lokasi pertuturan itu berlaku. Ahli bahasa akur bahawa belum ada instrumen yang cukup kuat untuk menilai peralihan bahasa dalam skala yang besar. Jikalau seorang individu yang terlibat dalam kajian buat pertama kali seperti dalam kajian ini, analisis yang lebih tepat memerlukan log masa komunikasi jangka panjang, iaitu yang dilakukan secara terperinci untuk jangka waktu agak lama dalam bahasa yang mereka digunakan sekali gus membandingkannya dengan penilaian yang sama pada waktu sebelumnya. Ini melibatkan juga interaksi peribadi seseorang itu dalam beberapa keadaan. Penyelidikan seperti ini adalah proses yang sangat sukar dan memerlukan tempoh masa yang lama.

Pada skala besar, banci seperti ini dibuat di kebanyakan negara bagi memperoleh maklumat mengenai penggunaan satu-satu bahasa itu. Maklumat yang diminta adalah mengenai penggunaan bahasa agak umum. Penggunaan bahasa di rumah dan dalam linkungan sosial yang berbeza adalah tidak dikaji secara terperinci. Semua soalan ini boleh 
menghasilkan data yang sangat berbeza jika kita melibatkan tahap interpretasi yang subjektif dan pelbagai. Kajian seperti ini perlu diulang dengan cara yang lebih terperinci seperti yang dilakukan dalam tahun 1990an oleh sarjana bahasa Melayu yang berkaitan tentang interaksi sosial masyarakat Melayu.

Secara umumnya, data statistik yang menunjukkan penggunaan bahasa Inggeris yang meningkat tidak dapat dinafikan. Hal ini akan lebih jelas lagi jika satu penilaian yang lebih teliti atau secara lebih lanjut dibuat semula terhadap pengajaran dan pembelajaran bahasa Melayu dalam sistem pendidikan di Singapura. Kebanyakan pelajar yang pergi ke institusiinstitusi pos menengah seperti Institut Pendidikan Teknikal (ITE), politeknik-politeknik dan ke maktab-maktab rendah kemudian ke universiti selepas meninggalkan sekolah menengah tidak lagi perlu mengambil bahasa Melayu sebagai mata pelajaran utama terutama yang dalam aliran teknikal, sains, teknologi dan perusahaan. Kursus-kursus profesional seperti perundangan, perhubungan dan banyak pekerjaan dalam ekonomi dan yang tinggi dijalankan dalam bahasa Inggeris. Malah pekerjaan dalam perkhidmatan awam menekankan kelulusan bahasa Inggeris dalam sijil am tempatan.

Oleh sebab semakin ramai berpendidikan pos-menengah lulus dari sistem pendidikan nasional yang menitikberatkan pencapaian dalam bahasa Inggeris, pendedahan kepada bahasa ibunda khususnya bahasa Melayu juga semakin berkurangan. Pendedahan kepada mata pelajaran lain seperti sastera dan sejarah alam Melayu dalam bahasa Melayu turut mengecil. Kekurangan pendedahan dalam ilmu bahasa Melayu juga menjejaskan penguasaan bahasa Melayu dalam bidang-bidang khusus seperti sains, teknikal malah dalam bidang bahasa dan kesusasteraan Melayu. Kemerosotan dalam angka penggunaan bahasa Melayu juga telah dikaji oleh beberapa ahli bahasa di NTU. Ada kajian yang merujuk kepada penghakisan bahasa masyarakat Melayu Singapura yang menyamai kadar penghakisan bahasa Afrikaan di Afrika Selatan.

"Hakisan bahasa Afrikaan berlaku secara beransur-ansur di Afrika Selatan sangat menyerupai keadaan orang Melayu di Singapura. Bahasa Melayu adalah bahasa yang selama ini dipelihara jauh lebih baik daripada bahasa minoriti lain yang dituturkan di Singapura. Walau bagaimanapun, peningkatan bahasa Inggeris sebagai bahasa ekonomi global di seluruh dunia dan penekanan pada bahasa Inggeris sebagai bahasa pengantar di Singapura bermakna bahawa masyarakat Melayu semakin menunjukkan tanda-tanda yang jelas beralih dari bahasa tradisional mereka.

(Cavallaro, 2010)

Pelbagai pengarang telah membincangkan peralihan bahasa dalam pelbagai komuniti Singapura, misalnya, Li et al. (1997) bagi bahasa Teochew; Schiffmann (2003) untuk bahasa Tamil; dan Gupta dan Siew (1995) bagi peralihan penutur Kantonis ke bahasa Mandarin di Singapura. Kajian-kajian ini telah dilakukan lebih kurang dua dekad lalu dan gejala peralihan dan pergeseran bahasa ini telah dikesan dalam kalangan orang Melayu di Singapura. Peralihan bahasa dan penggunaan bahasa adalah kurang ketara kerana sehingga sekarang hal ini masih mendapat perhatian walaupun ada tanggapan yang menyatakan bahawa tidak terdapat ancaman pemindahan bahasa yang kritikal kerana bahasa ini masih dipantau oleh pemerintah dan pemeliharaan bahasa tertakluk dalam perlembagaan selagi bahasa masih digunakan oleh orang Melayu. 


\section{Usaha-usaha untuk Melestarikan Penggunaan Bahasa Melayu}

Seiring dengan usaha memelihara bahasa Melayu, terdapat juga usaha-usaha bagi melestarikan penggunaan bahasa Melayu daripada pelbagai pihak contohnya pihak Kementerian Pendidikan (MOE) dan jawatankuasa-jawatankuasa yang dibentuk untuk menangani kemerosotan penggunaan bahasa Melayu.

Secara amnya, trend 'peralihan bahasa' juga berlaku dengan peratusan yang tinggi dalam kalangan masyarakat Cina di Singapura. Dalam sambutan Kempen Bahasa Mandarin ke-40 2019, akhbar Cina menukil Encik Lee, Perdana Menteri sebagai berkata "Singapore must guard against losing its bilingual edge" (Singapura perlu terus berwaspada daripada hilangnya daya kedwibahasaan) dalam teks ucapan yang disampaikan oleh beliau di pesta sambutan kaum Cina di sini.

Menurut statistik dari kajian yang dibuat oleh Kementerian Pendidikan Singapura (MOE) pula, dalam tahun 2019, 71 peratus isi rumah Cina dengan anak-anak yang masuk ke Sekolah Rendah Darjah 1, berbahasa Inggeris di rumah dalam tahun itu. Berdasarkan data bancian penduduk Singapura pada tahun 2000, 35.8 peratus kanak-kanak pada peringkat umur 5 hingga14 tahun yang berketurunan Cina menggunakan hanya bahasa Inggeris sahaja di rumah, manakala dalam kumpulan umur dari 15 hingga 24 tahun, 21.5 peratus menggunakan hanya bahasa Inggeris dalam perbualan dalam keluarga. Statistik menunjukkan penggunaan bahasa Inggeris yang semakin menyerlah dalam setiap lapisan kaum.

Sejak tahun 1984, bahasa Cina juga seperti bahasa Melayu telah menjadi satu subjek yang diambil di sekolah rendah dan sekolah menengah oleh 'penutur asli'nya dan semua mata pelajaran yang lain diajar dalam bahasa Inggeris. Oleh yang demikian, tidak hairanlah berlaku pemindahan bahasa kepada bahasa Inggeris yang terus menguasai sistem pendidikan di negara ini. Pelbagai usaha telah dilakukan untuk memperkenalkan bahasa ibunda dan terus menarik dan mengekalkan minat para pelajar terhadap perlestarian bahasa-bahasa ibunda.

Dari sudut yang lain, satu lagi tinjauan oleh Majlis Seni Kebangsaan (NAC, 2015) pada 2015 mendapati hanya sekitar 44 peratus daripada rakyat Singapura dan penduduk tetap yang berusia 15 tahun ke atas yang membaca sekurang-kurangnya senaskhah buku berbentuk penulisan sastera. Ini jauh sekali berbanding dengan jumlah pembaca sedemikian di Amerika Syarikat yang mencecah 70 peratus. Hal ini telah mendorong Lembaga Perpustakaan Negara (NLB) melancarkan kempen setiap lima tahun yang dipanggil "Gerakan Membaca Kebangsaan", yang bertujuan untuk lebih menggalakkan tabiat membaca dalam bahasa ibunda dan bahasa Inggeris.

Walau bagaimanapun, keadaan penggunaan bahasa Melayu yang semakin berkurangan ini tidak dikaitkan dengan masalah yang runcing, iaitu berdasarkan kajian yang dijalankan oleh Institut Dasar Singapura (IPS, 2020) baru-baru ini. IPS melaporkan lebih daripada 86 peratus daripada semua responden beranggapan yang bahasa adalah penanda paling sesuai sekurang-kurangnya dalam memberikan keunikan dalam identiti etnik mereka. Dalam kajian ini juga, orang Melayu (lebih daripada 70 peratus daripada peserta berbangsa Melayu) yakin bahawa mereka mempunyai hubungan emosi yang kuat dengan bahasa Melayu walaupun mereka lebih kerap berbahasa Inggeris. Apakah kesan daripada data yang disorot ini? 
Daripada kajian IPS ini juga, orang Melayu sendiri berpendapat kurangnya penggunaan bahasa tidak semestinya mengurangkan hubungan mereka dengan budaya mereka sendiri walaupun mungkin perspektif mereka terhadap budaya Melayu berbeza daripada perspektif budaya yang dipelajari melalui bahasa di sekolah. Data daripada responden bahasa Melayu dalam kajian tersebut, cenderung menekankan penguasaan bahasa masih dijaga dan sentiasa dikemas kini di sekolah-sekolah dan bawah jagaan dalam pemantauan Kementerian Pelajaran.

Orang Melayu juga cenderung menekankan penguasaan bahasa sebagai penanda identiti etnik mereka, kerana 95.7 peratus responden dalam kajian ini beranggapan bahawa kemahiran membaca, menulis dan bertutur dalam bahasa Melayu masih lagi sangat penting. Orang Melayu juga lebih cenderung menganggap penanda ini sebagai penting (71.9 peratus) walaupun 23.8 peratus beranggapan sebaliknya. Penanda ini adalah penanda baik menunjukkan masih ada kaitan yang kuat untuk menguasai bahasa sebagai penilai jati diri orang Melayu di sini. Ini memberikan harapan bahawa orang Melayu masih menitikberatkan penggunaan bahasa Melayu sebagai wadah penyaluran idea dan budaya dalam kehidupan mereka.

Tambahan pula, dalam kajian ini, responden Melayu turut menunjukkan kecenderungan paling besar untuk menggunakan bahasa Melayu dengan bapa mereka berbanding dengan rakan mereka yang berasal daripada golongan etnik yang lain. Data ini juga konsisten dalam semua peringkat umur dan peringkat pendidikan. Lebih 80 peratus responden Melayu menunjukkan mereka paling kerap menggunakan bahasa Melayu ketika berbual dengan ayah mereka. Kadar ini secara beransur-ansur meningkat antara kumpulan umur (lihat gambar rajah 3).

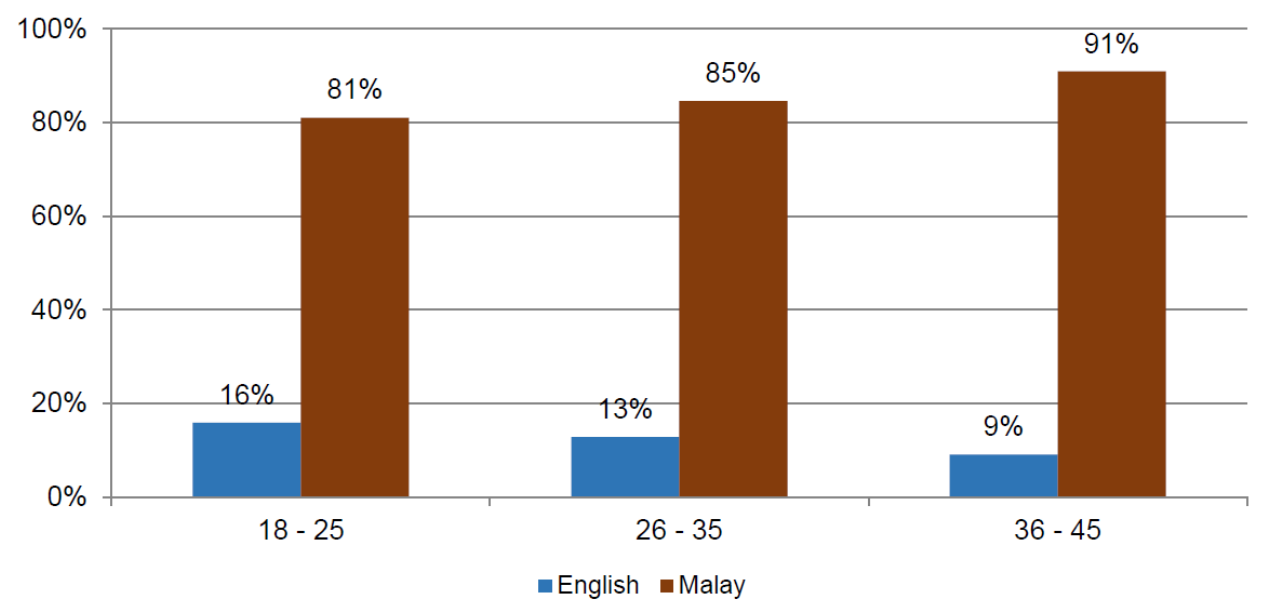

Rajah 3: Penggunaan bahasa Melayu dengan bapa mengikut peringkat umur (IPS: 2020)

Walaupun kecenderungan orang Muda Melayyu di Singapura berbahasa Inggeris di tempat kerja dan di rumah masih agak tinggi, dan kajian lain pula menegaskan bahawa mereka mempamerkan keselesaan dalam berbahasa Melayu (Cavallaro, 2010). Mereka cenderung untuk menggunakan lebih banyak bahasa Inggeris apabila mereka berhubung dengan rakan kerja terutamanya daripada golongan institusi pengajian dan berpendidikan 
tinggi. Sebaliknya, mereka menggunakan bahasa Melayu apabila bercakap dengan ahli keluarga atau ibu bapa mereka.

Oleh sebab terdapat kepercayaan bahawa pemerintah komited terhadap idea dwibahasa dan dasar pendidikan di Singapura tidak dapat mengubah kesan peralihan bahasa, langkah-langkah praktikal dan berkesan dapat dicapai untuk memastikan bahasa dalam lingkungan penutur bahasa Melayu tidak berkurangan kerana masih terdapat bilangan penutur bahasa Melayu dalam masyarakat yang masih cekap dan mencukupi bagi terus mengekalkan penggunaan bahasa ini.

\section{Usaha Melestarikan Penggunaan Bahasa Melayu}

Prinsip dwibahasa yang diwajibkan dalam kurikulum sekolah di negara ini membantu dalam usaha pelestarian bahasa Melayu. Selain menjadi bahasa kebangsaan, Bahasa Melayu diharapkan dapat juga:

“...berperanan sebagai bahasa penting bagi penyaluran idea, pemikiran dan budaya serta penjalinikatan masyarakat sepanjang zaman. Oleh yang demikian, kesinambungan penggunaan bahasa penting bagi membina dan mengekalkan jati diri masyarakat. Di samping itu, penguasaan bahasa Melayu juga membolehkan warga Singapura merebut peluang di rantau yang berkembang pesat dan menjalin hubungan khususnya dengan warga lain di rantau ini."

(Sukatan Pelajaran BM Sekolah Menengah, 2011)

Pendedahan kepada bahasa Melayu yang semakin berkurangan telah mendorong Kementerian Pendidikan Singapura (MOE) memperkenalkan beberapa program seperti Program Elektif Bahasa (LEP) (MOE, 2019) kepada tiga lagi sekolah menengah. Kini program ini hanya boleh didapati pada peringkat maktab rendah (JC).

Menurut MOE, ini adalah sebahagian daripada usaha untuk menyokong pelajar dalam meneruskan kesungguhan dan minat mereka untuk mendalami penguasaan pelajar bahasa ibunda (MTLs) dan sastera dalam konteks bahasa dan sastera mereka. Mulai 2020, LEP diperkenalkan pada peringkat menengah dan program ini diperluaskan lagi di maktab-maktab rendah yang lain. Usaha pada peringkat ini belum menampakkan hasilnya kerana baru diperkenalkan. Ini menunjukkan terdapat gagasan dan tindakan bagi memastikan bahawa pelajar-pelajar bahasa Melayu terus didedahkan dengan bahan-bahan sastera dalam bahasa Melayu.

Pelbagai usaha juga dibuat bagi menambah domain penggunaan Bahasa Melayu. Dengan terdapatnya berjenis-jenis media sosial dan laman sesawang dalam bahasa Inggeris, penutur muda bahasa Melayu juga diberikan ruang dan peluang dalam pelbagai platform bagi meneruskan penggunaan bahasa Melayu mereka. Media-media tempatan berbahasa Melayu juga telah menggunakan pelbagai platform media sosial bagi rancangan-rancangan dibuat secara langsung seperti di Facebook (contohnya saluran berita dan informasi seperti Mediacorp Warna 942 dan Beritamediacorp), Instagram dan Twitter. Dalam hal ini 
penyelidikan terperinci perlu dilakukan bagi memantau penggunaan aplikasi komputer bahasa Melayu dalam kalangan pelajar-pelajar Melayu yang dapat memberi gambaran penggunaan bahasa Melayu dalam laman sesawang.

\section{Pengguna Bahasa Melalui Bulan Bahasa}

Sebagai usaha agar bahasa Melayu terus diguna pakai oleh masyarakat Melayu dan bahasa Melayu terus kekal baku, dinamik dan dibanggakan oleh penggunanya, pemimpin-pemimpin masyarakat Melayu turut menubuhkan Majlis Bahasa Melayu Singapura (MBMS) melalui usaha bersama sekolah-sekolah, guru-guru dan masyarakat umum.

Sebagai langkah proaktif memartabatkan bahasa Melayu, MBMS, melancarkan 'bulan bahasa'. Pada mulanya program ini dianjurkan setiap dua tahun sekali, tetapi kini dianjurkan pada setiap tahun oleh Jawantankuasa Bahasa Melayu Singapura (JBMS) dengan kerjasama Majlis Pusat, Persatuan Wartawan Melayu Singapura dan dua belas badan-badan bahasa dan budaya yang lain. Terdapat peningkatan dalam sambutan masyarakat terhadap aktivitiaktiviti bahasa dan budaya yang dianjurkan terutama dalam talian dan maya. Namun, tumpuan aktiviti-aktiviti bahasa masih terhadap pengguna bahasa Melayu di sekolah-sekolah dan ibu bapa bagi para pelajar yang masih bersekolah. Ini mengkukuhkan lagi pandangan bahawa orang Melayu Singapura masih 'mencintai' bahasa mereka (IPS, 2020).

Memandangkan bahasa Melayu adalah subjek yang wajib bagi semua kanak-kanak yang menghadiri sekolah arus perdana maka bahasa ibunda masih dilihat mempunyai peranan penting dalam melestarikan identiti penuntut Melayu Singapura. Dasar dwibahasa menyebabkan terbentuk persepsi bahawa bahasa Melayu sebagai komponen penting yang mampu membentuk identiti etnik seseorang.

Pemerintah akur akan penekanan ini dan berusaha menambah lebih banyak lagi kegiatan bahasa bagi menggalakkan dan mempromosikan peri pentingnya penggunaan dan pelestarian bahasa ibunda (Malik, 2020). Usaha terkini termasuk menambah nilai pertubuhan seperti pertubuhan Wisma Geylang Serai yang aktif mengadakan acara-acara bahasa dan budaya Melayu, termasuk dalam talian. Pelbagai kegiatan dan peluang disajikan untuk meluaskan penggunaan bahasa Melayu dalam membantu meningkatkan kesedaran pelajar dan masyarakat tentang nilai dan kepentingan bahasa Melayu yang harus terus dipertingkatkan.

\section{Fenomena Peralihan Bahasa dan Usaha Pelestarian}

Perkara yang ditakuti oleh mana-mana golongan minoriti dalam sesebuah negara adalah 'peralihan bahasa' yang berterusan yang mengakibatkan 'language death' (pupus bahasa) (Fishman, 1991). Fenomena ini dibincangkan oleh ahli bahasa, terutama Fishman yang menyarankan beberapa langkah bagi menangani masalah "keciciran" bahasa. Salah satu kesan peralihan bahasa yang akan mengganggu proses dalam pembentukan masyarakat adalah apabila proses "sosialisasi", yang juga dikenali sebagai socialisation atau proses penerapan nilai sosial budaya kepada individu di dalam sesebuah keluarga dalam masyarakat. Proses awal sosialisasi di rumah akan terganggu jika kanak-kanak tidak didedah kepada bahasa ibunda yang mantap dari awal pertumbuhan kognitif kanak-kanak. Pelbagai masalah 
pembelajaran akan timbul jika pertumbuhan awal kanak-kanak tidak terbina dengan kukuh. Penyelidikan ini memerlukan penelitian yang berbeza dari segi pembentukan awal penguasaan bahasa kanak-kanak yang juga memerlukan kajian-kajian yang lebih terperinci dalam bidang ini.

Kanak-kanak dibesarkan dengan penggunaan bahasa Inggeris dan kurang terdedah kepada bahasa Melayu sejak lahir dan lama kelamaan penggunaan bahasa Melayu bukan lagi sebagai bahasa utama dan pertama di rumah. Hal ini mempunyai implikasi dan impak terhadap proses pemasyarakatan orang Melayu yang kebanyakannya beragama Islam. Proses ini akan membawa kepada orang Melayu Singapura menggunakan bahasa Inggeris dan menjadi 'ekabahasa' di rumah pada masa akan datang.

Pengkaji seperti Bloom yang telah mengkaji pembentukan awal pembangunan pemikiran (Armstrong, 2010) yang berpendapat bahawa pendedahan kepada perbendaharaan kata dapat mengkukuhkan cara berfikir dengan cara berperingkat. Berkaitan ini, pendedahan yang berkurangan kepada Bahasa Melayu akan memberi kesan kepada pembentukan perbendeharaan kata bahasa Melayu kerana hal ini tidak didedahkan lebih awal dan akan mengongkong pembentukan pemikiran seseorang kanak-kanak itu kerana tidak terbentuk dengan kukuh. Ini bermakna akan berkurangan lagi keupayaan berfikir dalam bahasa ini bagi tahap-tahap pemikiran yang lebih tinggi.

Jika karya-karya sastera, sejarah dan agama dalam bahasa Melayu di Malaysia, Singapura dan di rantau ini tidak lagi dikenali di sekolah-sekolah kerana tidak ada pendedahan langsung di sekolah-sekolah kebangsaan, maka ini akan menjejas penggunaan dan perkembangan bahasa ibunda.

Usaha memperkenalkan sastera di sekolah-sekolah dianggap juga satu usaha menangani masalah kurangnya penguasaan bahasa dan pengetahuan tentang masyarakat itu sendiri. Usaha melestarikan bahasa Melayu sepatutnya diiringi dengan mengadakan beberapa kelas yang menggunakan kata pengantar bahasa Melayu di sekolah-sekolah kebangsaan seperti yang terdapat pada masa lalu di mana kelas seni muzik, kraf tangan dan tukang dilakukan dalam bahasa Melayu bagi meluaskan perbendaharaan kata.

\section{Kesan Terhadap Masyarakat yang Mahu Belajar Bahasa Melayu}

Keadaan penggunaan bahasa Inggeris yang menjadi kebiasaan ini dapat menimbulkan kesan pada masa akan dating tambahan lagi apabila berlakunya kekurangan bahan pengajaran bersifat autentik. Hal ini sudah pasti menyulitkan lagi pembelajaran bahasa Melayu terutama kepada golongan yang bukan Melayu yang ingin belajar menggunakan bahasa Melayu. Semakin sukar juga mencari konteks penggunaan bahasa Melayu di luar bilik darjah. Dari segi pendidikan, pencapaian dalam bahasa Inggeris sememangnya telah mendorong ke tahap pencapaian yang amat cemerlang. Contohnya, dalam pencapaian kelulusan pendidikan tinggi ${ }^{3}$ menunjukkan tahap yang cemerlang dalam pencapaian Sains dan Matematik ${ }^{4}$ dengan berbahasa Inggeris.

\footnotetext{
${ }^{3}$ Kedudukan Universiti Nasional Singapura [NUS] sebagai universiti terbaik di Asia yang menggunakan berbahasa Inggeris sebagai bahasa pengantar.
} 
Pengalaman mengajar bahasa Melayu di Universiti Nasional Singapura kepada yang bukan Melayu menunjukkan tujuan mempelajari Bahasa Melayu adalah berbeza-beza. Ramai yang mahu belajar bahasa Melayu terutama daripada kumpulan pelajar kerja sosial dan perubatan dan kejururawatan. Mereka mahu mempelajari bahasa Melayu sebagai alat berkomunikasi dengan pelanggan di tempat-tempat kerja yang memerlukan interaksi dengan pengguna bahasa Melayu (selalunya untuk berinteraksi dengan orang-orang lebih dewasa atau warga emas).

Penggunaan bahasa dalam kelompok ini menjurus kepada memberikan khidmat yang khusus dalam bidang sosial atau perubatan. Tidak ramai yang mahu meneruskan pengajian bahasa Melayu atas sebab ilmiah seperti mendalami kajian dalam alam Melayu. Jarangjarang sekali, terdapat keinginan mahu belajar hingga benar-benar mahir dalam berbahasa. Hanya segelintir sahaja yang mahu bekerja di rantau ini akan bermotivasi untuk belajar bahasa Melayu. Oleh sebab kurang pendedahan, ramai pelajar yang belajar bahasa Melayu sebagai bahasa elektif tidak mahu meneruskan pembelajaran mereka dalam mempertingkatkan penguasaan dan penggunaan bahasa Melayu.

\section{Saranan bagi Meningkatkan Penggunaan Bahasa Melayu}

Melalui sisi pengajaran bahasa Melayu, ramai guru masih dibelenggu oleh beberapa aspek pedagogi yang lama. Ada tenaga pengajar yang terbiasa dengan kaedah yang memberikan nota dan penekanan terhadap satu aspek bahasa sahaja seperti tatabahasa. Sukatan pelajaran yang lebih peka dengan perkembangan bahasa dan budaya setempat dapat menarik minat para pelajar. Sastera juga sudah mula diperkenalkan dan diterapkan dalam kurikulum bukan sahaja dikuasai para sasterawan, pembaca dan pengkritiknya. Malahan diuar-uarkan kepada pelajar dan pengguna bahasa secara am. Sikap ingin menerapkan bahasa dalam kalangan orang muda ini juga akan meningkatkan minat terhadap kesusasteraan dan sejarah alam Melayu. Kesimpulannya, tugas memupuk, menggalak dan mengiktiraf bahasa dan sastera harus menjadi kepedulian dan ikhtiar dalam perancangan dasar bahasa. Sekiranya sastera berkembang subur dalam masyarakat, maka sedikit sebanyak akan dapat menjadi pemacu kesedaran, penerang kenuranian, dan membawa ke peringat kepedulian.

\section{Kesimpulan}

Ringkasnya, peralihan bahasa (language shift) adalah fenomena linguistik yang menarik dan tidak dapat dielakkan. Terutama dalam masyarakat minoriti yang tinggal di dalam negara yang mengamalkan dasar dwibahasa yang bersandar kepada satu bahasa yang dominan. Faktor-faktor lain seperti pemodenan yang pesat menyebabkan kesan pergeseran bahasa berbeza daripada satu komuniti bahasa ke satu komuniti bahasa yang lain. Masyarakat Melayu di Singapura yang lahir di Singapura menghadapi proses peralihan bahasa daripada bahasa tempatan datuk nenek mereka [bahasa Jawa, bahasa Bugis, Bawean, Arab dan kelompok minoriti dari pelbagai daerah di Riau dan di Malaya sebelum kemerdekaan] kepada bahasa Melayu. Kemudian terjadi peralihan bahasa masyarakat akibat dasar bahasa Inggeris sebagai bahasa nasional. Pada masa sekarang ini secara perlahan berlaku peralihan bahasa

\footnotetext{
${ }^{4}$ Ujian Kompetensi Global PISA: Dalam ujian Kompetensi Global, yang dilakukan sebagai sebahagian daripada Program Penilaian Pelajar Antarabangsa (Pisa), pelajar Singapura memperoleh rata-rata markah yang lebih baik daripada rakan sebaya mereka dari Kanada, Hong Kong, Scotland dan Taiwan, 22 Oktober 2020.
} 
kepada bahasa Inggeris, iaitu bahasa Inggeris digunakan secara meluas dalam setiap aspek kehidupan orang Melayu di Singapura.

Dalam keadaan Singapura moden bersedia menjadi pusat teknologi tinggi dan memasuki era digital 4.0, faktor-faktor demografi, sikap dan nilai, faktor ekonomi, sosiobudaya dan politik akan terus mempengaruhi penggunaan bahasa Melayu dan budaya tempatan. Menurut Chew Fong Peng \& Zahari Ishak (2008), fenomena globalisasi dan era teknologi maklumat telah memberi kesan terhadap penggunaan bahasa Melayu dan Inggeris dalam sistem pendidikan negara. Persoalan tentang bagaimana bahasa Melayu sebagai bahasa kaum minoriti dapat dikekalkan akan terus dipantau. Jika bahasa dianggap sebagai simbol penting identiti kumpulan minoriti, pengguna bahasa akan terus mengguna dan memelihara bahasa itu. Sokongan institusi secara amnya akan dapat mempertahankan bahasa kumpulan minoriti ini. Pendidikan, undang-undang dan pentadbiran, agama dan media merupakan domain-domain penting yang masih boleh melestarikan penggunaan bahasa Melayu dan patut diberikan perhatian.

\section{Pengekalan dan Bahasa Ibunda Dalam Situasi Minoriti}

Pemeliharaan bahasa boleh berterusan selagi bahasa masih diajar dan dilihat sebagai aspek penting dalam kehidupan berbudaya di Singapura. Komuniti penutur bahasa mesti menyokong dan menjalankan aktiviti pemeliharaan bahasa seperti saranan ahli bahasa (Fishman, 1999). Ahli bahasa mungkin harus menerima bahawa sesetengah masyarakat mungkin tidak lagi menjaga bahasa warisan mereka. Pembelajaran bahasa harus juga dikaitkan dengan kedudukan geo-politik negara Singapura. Pelajar-pelajar juga harus didedahkan tentang kedudukan geo-politik di tengah-tengah kumpulan negara-negara berbangsa dan berbahasa Melayu. Pengetahuan bahasa harus diseragamkan dengan pengetahuan tentang sejarah rantau ini kerana penyelidikan menunjukkan bahawa mengetahui peraturan tatabahasa tidak semestinya menghasilkan pertuturan atau penulisan yang baik dan rasa empati masyarakat Melayu. Pelajar yang telah menghafal peraturan bahasa mungkin berjaya dalam ujian standard bahasa Melayu, tetapi mungkin tidak dapat bertutur dan memahami budaya setempat, apatah lagi untuk memahami budaya dan nilai-nilai orang Melayu di rantau ini.

Akhir sekali, peralihan bahasa adalah satu fenomena linguistik yang tidak dapat dielakkan terutama dalam masyarakat yang menitikberatkan pencapaian pendidikan dalam bahasa Inggeris. Sudah terdapat tanda-tanda awal peralihan bahasa dalam masyarakat Melayu Singapura. Pendekatan sosiolingustik yang memerlukan perincian dalam penggunaan bahasa melalui demografi, sikap dan nilai-nilai budaya orang Melayu dan juga penggunaan bahasa dalam bidang-bidang lain seperti ekonomi, sosial, dan politik, akan terus mempengaruhi cara orang Melayu Singapura menggunakan bahasa mereka. Kemampuan berdwibahasa juga perlu ditekankan sekali gus memperdayakan pengguna bahasa dalam usaha penakatan bahasa ibunda mereka di samping menguasai bahasa yang dianggap sebagai bahasa antarabangsa.

\section{Rujukan}

Abdullah, Kamsiah \& Bibi Jan Ayyub. (1998). Malay language issues and trends. In S. Gopinathan, Anne Pakir, Ho Wah Kam \& Vanithamani Saravanan (eds.). Language, Society and Education in Singapore. Singapore: Federal Publications, pp. 179-190. 
Adegibija, E. (2001). Saving threatened languages in South Africa: A case study of Oko. In Fishman, Joshua, A. (2001). Can Threatened Languages Be Saved? Reversing Language Shift, Revisited: A 21st Century Perspective (2nd Edition). United Kingdom: Multilingual Matters, pp. 284-308.

Amstrong, P. (2010). Bloom's Taxonomy. Vanderbilt University Center for Teaching. Retrieved from https://cft.vanderbilt.edu/guides-sub-pages/blooms-taxonomy/.

Ager, Dennis. (2001). Motivation in language planning and policy. United Kingdom: Multilingual Matters.

All-Party Report. (1956). Report of the All-Party Committee of the Singapore Legislative Assembly on Chinese education. Singapore All-Party Committee on Chinese Education. Singapore: Government Printer.Constitution Of The Republic Of Singapore extracted from http://www.unesco.org/education/edurights/media/docs/c987002feca6f27ffc5d2a18b4 488280df3c3362.pdf. 75 .

Anthea Fraser Gupta and Siew Pui Yeok. (1995). Language shift in a Singapore family. Journal of Multilingual and Multicultural Development, Issue 4, Vol. 16, 1995, pp. 301-314.

Cavallaro, Francesco. (2010). Language use and language shift among the Malays in Singapore $\quad$ in Applied Linguistics Review. 1 June, pp. 129-170.

Chew Fong Peng \& Zahari Ishak. (2008). Tahap penggunaan Bahasa Melayu dan Bahasa Inggeris dalam kalangan mahasiswa/i IPTA dan IPTS dalam Sistem Pendidikan Negara. Jurnal Pengajian Melayu. Jilid 19, 2008.

Clyne, Michael. (2003). Dynamics of language shift. University of Melbourne. December. Cambridge University Press, pp. 20-69.

Department of Statistics. (2020). General houshold survey 2020 statistical release, socio demographic and economic characteristics. Singapore: Department of Statistics, Ministry of Trade and Industry. Department of Statistics, Singapore Government Agency Website: singstat.gov.sg. Infographics. Retrieved from https://www.singstat.gov.sg/-/media/files/publications/cop2020/sr1/infographics.pdf.

Diarmait, Mac Giolla Chriost. (2000). Language Planning in Northern Ireland. In Current Issues in Language Planning. Multilingual Matters 3(4), pp. 425-476.

Edwards, Johns. (1985). Language, society and identity. United Kingdom: Billing and Sons Ltd.

Fishman, Joshua A. (1999). Language and ethnic identity. New York: Oxford University Press.

Fishman, J. A. (1991). Reversing language shift: Theoretical and empirical foundations of assistance to threatened languages. Clevedon United Kingdom: Multilingual Matters. 
Fishman, Joshua, A. (1989). Language and ethnicity in minority a sociolinguistic perspective. United Kingdom: Multilingual Matters Ltd.

Fishman, Joshua A. (2001). Can Threatened Languages Be Saved? In Reversing language shift, revisited: A 21st century perspective (2nd ed). Clevedon: Multilingual Matters.

Kamsiah, Abdullah. (2000). Sikap dan motivasi penuntut Melayu di Sekolah Menengah Singapura terhadap bahasa Melayu dan bahasa Inggeris. Singapore: Pustaka Nasional.

Li Wei Vanithamani Saravanan and Julia Ng Lee Hoon. (1997). Language Shift in the Teochew Community in Singapore: A Family Domain Analysis. Journal of Multilingual and Multicultural Development. Issue 5, Volume 18.

Lee Hsien Loong. (2021). National Day Rally Speech 29th August 2021. Retrieved from https://www.pmo.gov.sg/Newsroom/National-Day-Rally-2021-Malay.

Lee Hsien Loong. (2019). 40 ${ }^{\text {th }}$ Anniversary speak Mandarin Campaign. Singapore: National Heritage Board. Singapore.

Institute of Policy Studies. IPS. (2020). Language proficiency, identity \& management. Survey on Language, Race \& Religion. Number 15, June.

Malay Language Learning and Promotion Committee (MLLPC). Retrieved from http://www.mllpc.sg.

Maliki, Osman. (2020). Ucapan di Majlis Ulang Tahun Ke-10 Pusat Bahasa Melayu Menteri Di Pejabat Perdana Menteri dan Menteri Kedua Pendidikan Merangkap Ehwal Luar Singapura, MOE, 23 November 2020.

Ministry of Education. (2021). Ministry of Education: Singapore extracted online 6 Aug 2021. Retrieved from https://www.moe.gov.sg/primary/curriculum/mother-tonguelanguages.

Ministry of Education. (2021). Ministry of Education: Singapore. Retrieved from https://www.moe.gov.sg/primary/compulsory-education.

Ministry of Education. (2019). Nurturing Passionate Learners of Mother Tongue Languages and Literature. Retrieved from http://www.moe.gov.sg/initiatives/compulsoryeducation/ (accessed 20 Aug 2021). Ministry of Education: Singapore.

National University of Singapore. (2007). The CLS Working Paper Series, No. 14 Towards Common Goals in Foreign Language Teaching and Learning: A Proposed Framework Syllabus for the CLS. Teaching Development Committee. Centre for Language Studies, NUS. 
National Arts Council. (2015). National literary reading and writing survey 2015. NAC: Singapore.

Pauwels, A. (2016). Language maintenance and shift: Key topics in sociolinguistics. Cambridge: Cambridge University Press.

Rokzana, Bibi. (1990). Penggunaan bahasa Melayu di Singapura: Satu kajian kes di Geylang. Sekata (Singapore). The Malay Language Council 8(1), pp. 31-39.

Schiffman, Harold F. (2003). Tongue-Tied in Singapore: A Language Policy for Tamil? Journal of Language Identity \& Education, April Vol. 2(2), pp. 105-125. 